\title{
PALEOMAGNETIC RESULTS FROM GRENVILLIAN-AGED ROCKS FROM OAXACA, MEXICO: EVIDENCE FOR A DISPLACED TERRANE
}

\author{
MARTHA M. BALLARD and ROB VAN DER VOO \\ Department of Geological Sciences, University of Michigan, Ann Arbor, MI 48109 (U.S.A.)
}

J. URRUTIA-FUCUGAUCHI

Instituto de Geofisica, Universidad Nacional Autonoma de Mexico, Delagacion Coyoacan 04510 D.F. (Mexico)

(Received February 22, 1987; revision accepted September 22, 1987)

\begin{abstract}
Ballard, M.M., Van der Voo, R. and Urrutia-Fucugauchi, J., 1989. Paleomagnetic results from Grenvillian-aged rocks from Oaxaca, Mexico: evidence for a displaced terrane. Precambrian Res., 42: 343-352.

In order to test the possibly displaced nature of the Proterozoic ('Grenville'-aged) Oaxaca terrane, a paleomagnetic study was carried out on gneissic and meta-igneous (anorthosite) rocks with metamorphic ages reported to be between 1100 and $900 \mathrm{Ma}$. Using alternating field (AF) and thermal demagnetization techniques, we have isolated two magnetic directions: a shallow and southerly direction $\left(D=155^{\circ}, I=-1^{\circ}\right)$ and a very steeply down direction $\left(D=6^{\circ}\right.$, $\left.I=+74^{\circ}\right)$. It seems likely that the shallow direction is a remagnetization associated with a slight reheating and cooling due to a nearby Permian-Triassic intrusion. The steep direction is interpreted as a magnetization acquired during uplift and cooling following the Oaxacan Orogeny, and gives a paleopole at $47^{\circ} \mathrm{N}, 93^{\circ} \mathrm{W}$ with an age of $\sim 950 \mathrm{Ma}$. This pole is at least $40^{\circ}$ from the Grenville Loop of the North American apparent polar wander path and the observed paleolatitude of $60^{\circ} \mathrm{N}$ is much higher than that predicted for Oaxaca if it had always belonged to North America in the same relative position it has today. The high paleolatitude obtained for the Oaxaca terrane does not preclude, however, that it was part of North America during Grenvillian times, but in that case its position would have been much closer to Ontario and Quebec than it is today.
\end{abstract}

\section{Introduction}

The paleogeographic position of the Paleozoic and Precambrian basement rocks of southern Mexico is unconstrained. This is owing, in part, to the fact that in much of Mexico, Mesozoic or younger rocks cover the surface, frustrating attempts at unravelling its earlier history. In southern Mexico, however, a large Precambrian basement complex is well exposed in the State of Oaxaca. This provides the opportunity for a paleomagnetic study of the Precambrian of southern Mexico.

While several hypotheses have been put forward regarding the pre-Mesozoic position of southern Mexico, many of these hypotheses are contradictory. The basement rocks of Oaxaca have been correlated with the Grenville Province of North America on the basis of lithologic similarities, metamorphic ages and structural 
trends (Fries et al., 1962; Engel, 1963; Kesler and Heath, 1970; Ortega-Gutierrez, 1986). In contrast, Whittington and Hughes (1974) have found that the Tremadocian trilobites found in sediments from Oaxaca are more similar to fossils from the Olenid-Ceratopygid province of Gondwana than the coeval Rasettia-Highgatella fauna typical of North America. The ambiguity about southern Mexico's paleogeographic position reflected by such conflicting hypotheses indicates that quantitative studies are necessary to understand the Precambrian position of southern Mexico better. A paleomagnetic study of the different lithologies exposed in the Oaxacan Complex could provide constraints on the otherwise ambiguous paleogeographic position of southern Mexico.

\section{Geology and sampling}

The Oaxacan Metamorphic Complex of southern Mexico (Fig. 1) has been metamorphosed to the granulite facies. This metamorphic event, hereafter to be referred to as the Oaxacan Orogeny (Fries et al., 1962), is of suf- ficient grade to reset completely the ages and the magnetization in these rocks. Mora and Valley (1985) have estimated that metamorphic peak temperatures and pressures were $730 \pm 50^{\circ} \mathrm{C}$ and $7 \pm 1 \mathrm{kbar}$, respectively. Radiometric ages of 1100-900 Ma have been determined by several techniques including $\mathrm{K}-\mathrm{Ar}$ dating of biotite from pegmatites (Fries et al., 1962; Fries and Rincon-Orta, 1965; Fries et al., 1974), Pb-alpha of zircons (Fries et al., 1962, 1966, 1974), Rb-Sr biotite dates (Fries et al., $1966)$ and $\mathrm{U}-\mathrm{Pb}$ dates of zircons found in gneiss and pegmatite (Anderson and Silver, 1971; Ortega-Gutierrez et al., 1977). Patchett and Ruiz (1987) determined dates for metamorphic garnets in the paragneiss and charnockite of $963 \pm 3$ and $938 \pm 4 \mathrm{Ma}$ for these two rock types, respectively, based on the $\mathrm{Sm}-\mathrm{Nd}$ isochron method. Furthermore, they assumed that the closure temperature for the garnets was $\sim 600^{\circ} \mathrm{C}$, in agreement with estimates of $500-$ $600^{\circ} \mathrm{C}$ obtained elsewhere (Humphries and Cliff, 1982). Cooling rates subsequent to isotopic closure of the garnets were estimated at $3.5^{\circ} \mathrm{C} \mathrm{Ma}^{-1}$, based on $\mathrm{Rb}-\mathrm{Sr}$ biotite/wholerock ages $50 \mathrm{Ma}$ younger than the $\mathrm{Sm}-\mathrm{Nd}$ ages
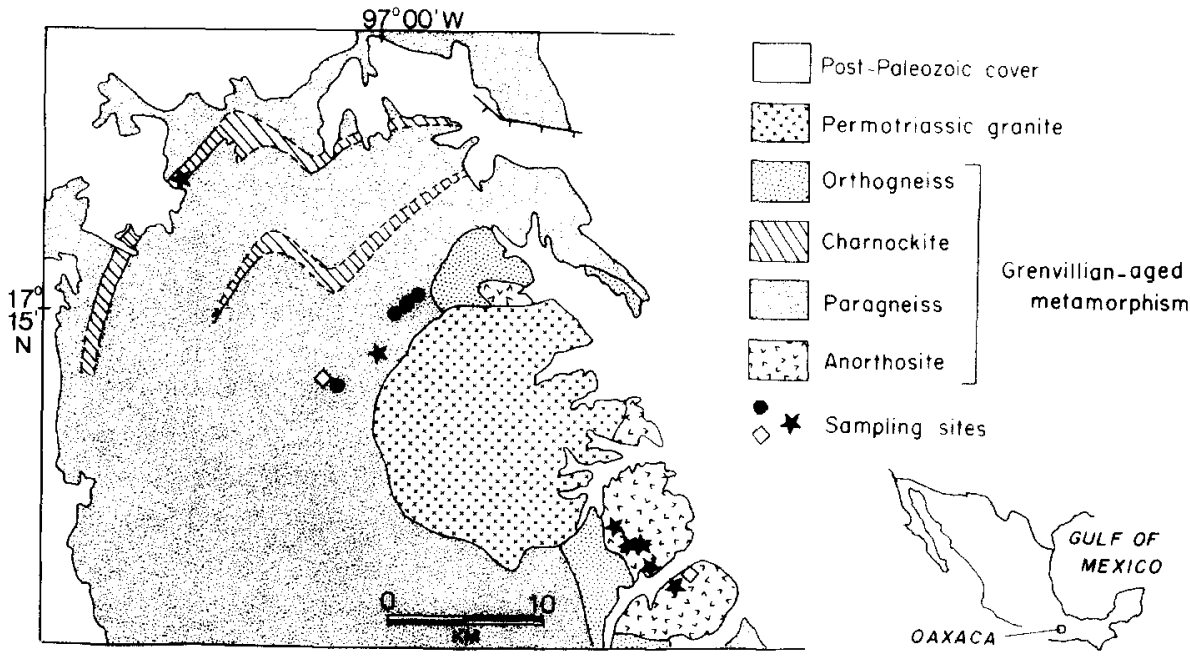

Fig. 1. Schematic geologic map of the northern part of the Oaxacan Complex in southern Mexico (after Ortega-Gutierrez, 1981 ) showing the sampling locations. $\diamond$ represents sites not used in the analysis; $\bigcirc$ represents sites where a southerly and shallow Late Paleozoic-Early Mesozoic direction was isolated; $\downarrow$ represents sites where a steep Precambrian direction was isolated. 
and assuming a Sr blocking temperature for the biotite of $\sim 300^{\circ} \mathrm{C}$.

The Oaxacan Complex is exposed along a 50-100-km-wide belt trending NNW-SSE in the central part of the State of Oaxaca. A metaanorthosite massif of intermediate composition, the dominant mineral present being andesine, is thought to be of magmatic origin on the basis of relict megacrystic-ophitic textures found in several parts of the massif. Orthogneiss ranging in thickness from 100 to $2000 \mathrm{~m}$ lies on top of the anorthosite (Ortega-Gutierrez, 1981). The lower part is interbanded with the anorthosite and consists of bands and lenses of ilmenite-magnetite-apatite (nelsonite) and apatite-ilmenite-rich gneisses. The upper part is dominated by gabbroic to granitic garnetiferous rocks. The orthogneiss is surrounded by a paragneissic sequence which can also be divided into two parts. The lower part is formed by Ca-rich banded gneisses with marble and scapolite-rich calc-silicates while the upper part consists primarily of pelitic gneisses rich in garnet, sillimanite and biotite, and charnockitic banded gneisses (Ortega-Gutierrez, 1981). The Complex is intruded by a post-metamorphic granitic pluton with a $\mathrm{Pb}$-alpha age of $240 \pm 30 \mathrm{Ma}$ (Fries et al., 1966) and a wholerock $\mathrm{Rb}-\mathrm{Sr}$ age of $272 \pm 8 \mathrm{Ma}$ (Ruiz-Castellanos, 1979). To our knowledge no reset Paleozoic/early Mesozoic ages have been reported for the Precambrian rocks away from the intrusion.

The Oaxacan Complex shows evidence of generally parallel N-S or NNW-SSE structural trends such as banding and foliation. Early folds are predominantly isoclinal and of extreme amplitude (De Cserna, 1971; Kesler, 1973) while later, but still pre- to syn-metamorphic, folds are mostly open in profile with vertical to subhorizontal axial planes (Kesler and Heath, 1970). The complex is bounded by mylonite belts for which the magnitude and sense of shear and the age of mylonitization have not yet been well established. There has been, however, only one extensive phase of metamorphism identified from the mineralog- ical assemblages of most lithologies. Metamorphic recrystallization accompanied the structural deformation that produced the banding and folding. Granulite assemblage minerals indicate intermediate pressure of formation (5-8 kbar) at high temperatures $\left(700-800^{\circ} \mathrm{C}\right)(\mathrm{Or}-$ tega-Gutierrez, 1981; Mora and Valley, 1985). The deformation and granulite metamorphism may have occurred during the intrusion of the gabbroic-anorthositic magmas or may have been associated with a continental collision event, as suggested by Dewey and Burke (1973) for the Grenville Orogeny (Ortega-Gutierrez, 1981). The major consequence of this Oaxacan (Grenvillian) event is that it certainly reset both the radiometric dates and the magnetizations of the anorthosite, paragneiss and charnockite which are the subject of this paleomagnetic study.

Because the peak metamorphic temperatures far exceeded the possible Curie temperatures for our rocks, and given that the metamorphism was contemporaneous with Oaxacan deformation, the structural deformation of the Oaxacan Orogeny preceded the acquisition of the magnetizations documented in this paper. This means that any possible structural corrections to be applied must only involve those deformations associated with post-Oaxacan events. There is no evidence for Cretaceous and younger deformation, given that flat-lying Cretaceous rocks are clearly observed in the field. No post-metamorphic deformation internal to our sampling area in the Oaxaca massif (Fig. 1) has been recognized. On the other hand, a small inlier of Paleozoic sedimentary rocks to the northwest of our area (near Santiago Ixtaltepec) shows westerly dips of $\sim 30^{\circ}$, but these tilts may only be of local significance. We will return to the question of structural tilts in the discussion.

We sampled three Precambrian lithologies in the hope of obtaining post-metamorphic, Precambrian magnetic directions. Standard 2.5$\mathrm{cm}$-diameter core samples were taken using a portable core drill. We collected 46 samples of 
paragneiss from six sites, 39 samples from six sites in the anorthosite massif and six charnockite samples from one site. These samples were then demagnetized and the results analyzed.

\section{Laboratory techniques}

The remanent magnetization of the standard paleomagnetic cores was measured using either a Superconducting Technology (ScT) cryogenic magnetometer or a Schonstedt SSM-1A spinner magnetometer. All measurements were made in a magnetically shielded room at the University of Michigan. To isolate characteristic directions, stepwise thermal demagnetizations were done in a Schonstedt TSD-1 model oven, whereas a Schonstedt GSD-1 AC Specimen Demagnetizer was used for alternating field (AF) demagnetizations. Isothermal remanent magnetization (IRM) experiments were conducted using a Lambda Electronics Corp. Regulated Power Supply and a Varian Associates V-4005 Magnet Assembly with a maximum field strength of $1.4 \mathrm{~T}$.

The magnetic direction remaining after each treatment was plotted using the orthogonal demagnetization diagrams by Zijderveld (1967). Characteristic magnetic directions were, in all cases, determined by principal component analysis (Kirschvink, 1980).

\section{Results}

Samples collected from the anorthosite massif, the paragneiss and the charnockite bands were demagnetized stepwise using either AF or thermal demagnetization. The results are summarized in Table I.

Of the 46 paragneiss samples, 34 were found to be suitable for paleomagnetic analysis. In the remaining 12 samples, no coherent magnetic direction could be isolated and these samples (including all the samples from one of the six sites ) were excluded from further analysis.

In general, the paragneiss samples revealed multivectorial behavior upon demagnetization. Using both AF and thermal demagnetization the samples from two of the sites revealed two components of magnetization (Fig. 2a). A lowtemperature $\left(<500^{\circ} \mathrm{C}\right)$ or low-coercivity $(<30$ $\mathrm{mT})$ component was isolated $\left(D=350^{\circ}\right.$,

TABLE I

Paleomagnetic results

\begin{tabular}{|c|c|c|c|c|c|c|c|}
\hline Site & Rock type & Location & $n / n_{\mathrm{o}}$ & $k$ & $\alpha_{95}$ & $D / I$ & Pole position \\
\hline \multicolumn{8}{|c|}{ Sites with steep magnetic direction } \\
\hline 1 & Charnockite & $97^{\circ} 07^{\prime} \mathrm{W} ; 17^{\circ} 18^{\prime} \mathrm{N}$ & $6 / 6$ & 43 & 10.3 & $220 /-67$ & $62^{\circ} \mathrm{W} ; 44^{\circ} \mathrm{N}$ \\
\hline 2 & Anorthosite & $96^{\circ} 49^{\prime} \mathrm{W} ; 17^{\circ} 05^{\prime} \mathrm{N}$ & $7 / 7$ & 59 & 7.9 & $0 /+64$ & $97^{\circ} \mathrm{W} ; 61^{\circ} \mathrm{N}$ \\
\hline 3 & Anorthosite & $96^{\circ} 51^{\prime} \mathrm{W} ; 17^{\circ} 06^{\prime} \mathrm{N}$ & $4 / 6$ & 64 & 11.5 & $28 /+60$ & $57^{\circ} \mathrm{W} ; 56^{\circ} \mathrm{N}$ \\
\hline 4 & Anorthosite & $96^{\circ} 52^{\prime} \mathrm{W} ; 17^{\circ} 07^{\prime} \mathrm{N}$ & $4 / 6$ & 29 & 17.5 & $161 /-58$ & $131^{\circ} \mathrm{W} ; 63^{\circ} \mathrm{N}$ \\
\hline 5 & Anorthosite & $96^{\circ} 53^{\prime} \mathrm{W} ; 17^{\circ} 07^{\prime} \mathrm{N}$ & $8 / 8$ & 106 & 5.4 & $285 /+75$ & $126^{\circ} \mathrm{W} ; 22^{\circ} \mathrm{N}$ \\
\hline 6 & Anorthosite & $96^{\circ} 53^{\prime} \mathrm{W} ; 17^{\circ} 08^{\prime} \mathrm{N}$ & $5 / 5$ & 21 & 17.0 & $325 /+76$ & $116^{\circ} \mathrm{W} ; 38^{\circ} \mathrm{N}$ \\
\hline 7 & Paragneiss & $97^{\circ} 00^{\prime} \mathrm{W} ; 17^{\circ} 14^{\prime} \mathrm{N}$ & $9 / 10$ & 316 & 2.9 & $103 /+74$ & $68^{\circ} \mathrm{W} ; 09^{\circ} \mathrm{N}$ \\
\hline Over & & $96^{\circ} 55^{\prime} \mathrm{W} ; 17^{\circ} 09^{\prime} \mathrm{N}$ & $7 / 7$ & 20 & 13.7 & $6 /+74$ & $93^{\circ} \mathrm{W} ; 47^{\circ} \mathrm{N}$ \\
\hline \multicolumn{8}{|c|}{ Sites with shallow, southerly magnetic direction } \\
\hline 1 & Paragneiss & $96^{\circ} 58^{\prime} \mathrm{W} ; 17^{\circ} 15^{\prime} \mathrm{N}$ & $5 / 5$ & 60 & 9.9 & $158 /-11$ & $147^{\circ} \mathrm{E} ; 66^{\circ} \mathrm{N}$ \\
\hline 2 & Paragneiss & $96^{\circ} 59^{\prime} \mathrm{W} ; 17^{\circ} 16^{\prime} \mathrm{N}$ & $6 / 11$ & 154 & 5.4 & $162 /+21$ & $117^{\circ} \mathrm{E} ; 57^{\circ} \mathrm{N}$ \\
\hline 3 & Paragneiss & $96^{\circ} 59^{\prime} \mathrm{W} ; 17^{\circ} 16^{\prime} \mathrm{N}$ & $7 / 10$ & 16 & 15.5 & $144 /+04$ & $148^{\circ} \mathrm{E} ; 50^{\circ} \mathrm{N}$ \\
\hline 4 & Paragneiss & $97^{\circ} 00^{\prime} \mathrm{W} ; 17^{\circ} 13^{\prime} \mathrm{N}$ & $7 / 7$ & 46 & 9.0 & $156 /-16$ & $155^{\circ} \mathrm{E} ; 65^{\circ} \mathrm{N}$ \\
\hline \multicolumn{2}{|c|}{ Overall mean } & $96^{\circ} 59^{\prime} \mathrm{W} ; 17^{\circ} 15^{\prime} \mathrm{N}$ & $4 / 4$ & 20 & 21.2 & $155 /-01$ & $141^{\circ} \mathrm{E} ; 60^{\circ} \mathrm{N}$ \\
\hline
\end{tabular}

$D=$ Magnetic declination; $I=$ magnetic inclination; $k=$ precision parameter; $\alpha_{95}=$ confidence interval; $n / n_{0}=$ number of samples used in calculations/total number of samples collected at that site. 

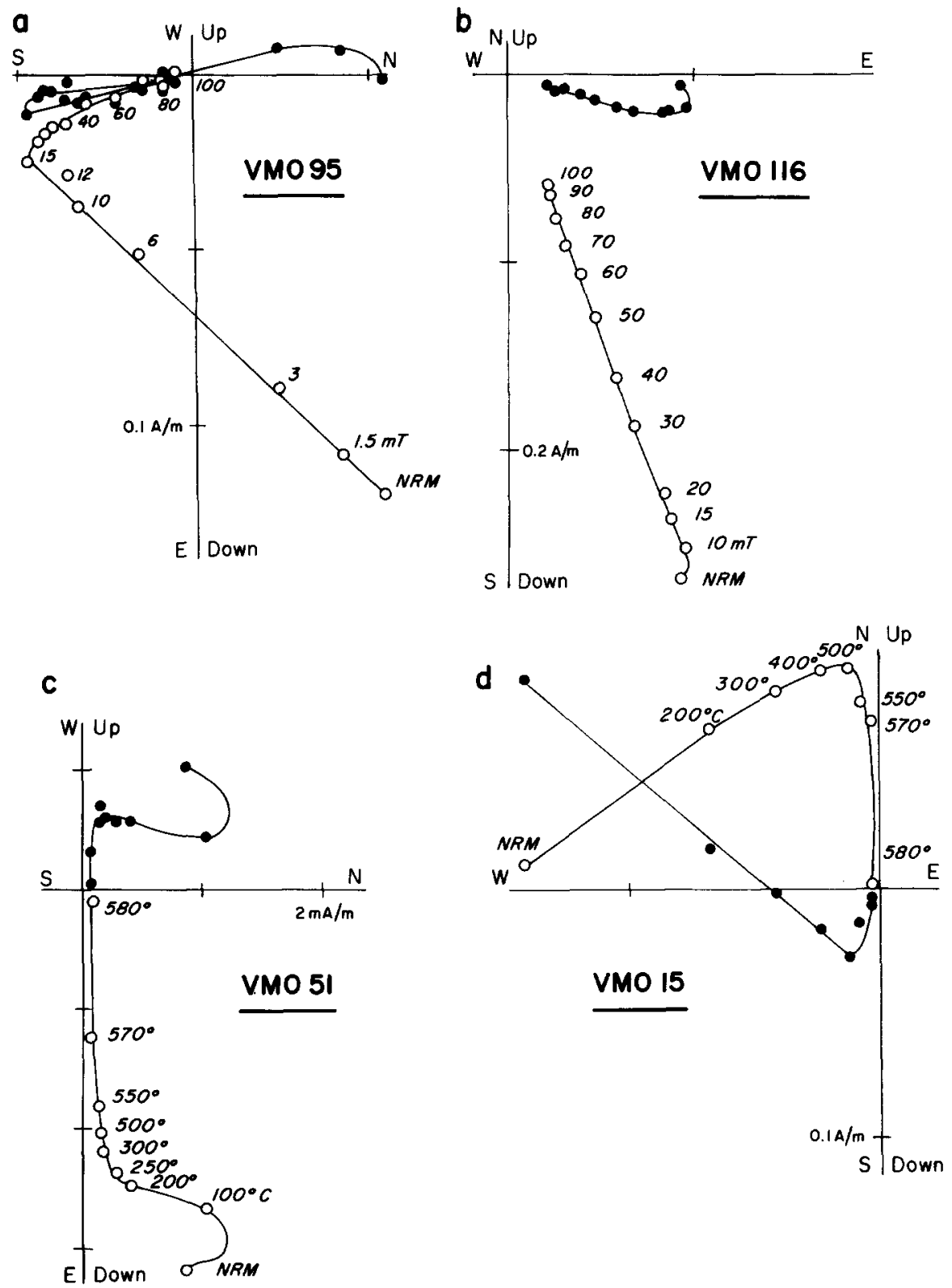

Fig. 2. Representative demagnetization diagrams (Zijderveld, 1967). $\bigcirc$ (O) represents projections onto vertical (horizontal) plane. (a) AF demagnetization of paragneiss showing present-day and southerly/shallow direction, (b) AF demagnetization of paragneiss showing steep Precambrian direction, (c) thermal demagnetization of anorthosite, (d) thermal demagnetization of charnockite.

$\left.I=+46^{\circ}\right)$. We interpret this northerly and intermediate downward direction to be a viscous present-day overprint.

The higher-temperature, higher-coercivity component, shown in Fig. 2a, was found in paragneiss samples from four sites and gave a mean direction of $D=155^{\circ}, I=-1^{\circ}$. This southerly and shallow direction is similar to insitu results obtained from the Permian Yododeñe Formation $\left(D=144^{\circ}, I=+7^{\circ}\right)$ (Gose and Sanchez-Barreda, 1981) as well as results reported by McCabe et al. (1984, 1985) from 
Paleozoic sediments adjacent to the Yododeñe Formation. McCabe et al. constrained the age of this magnetization to be younger than Permian and older than Cretaceous on the basis of a negative fold test and a positive conglomerate test respectively. All these results were interpreted by McCabe et al. (1985) as remagnetizations of Late Paleozoic-Early Mesozoic (pre-Cretaceous) age. The similarity of these results and the proximity of the paragneiss sites to the Permian-Triassic granitic pluton strongly suggest that the higher-temperature, higher-coercivity direction found in these paragneiss sites is a late Paleozoic to early Mesozoic overprint probably related to heating and cooling due to this intrusion. The conclusion that these sites were remagnetized and others (described below) were not, may be explained by the more distributed blocking temperatures of the paragneisses, as compared with the very high and discrete blocking temperatures of the other sites.

A very different result was found for the sam-

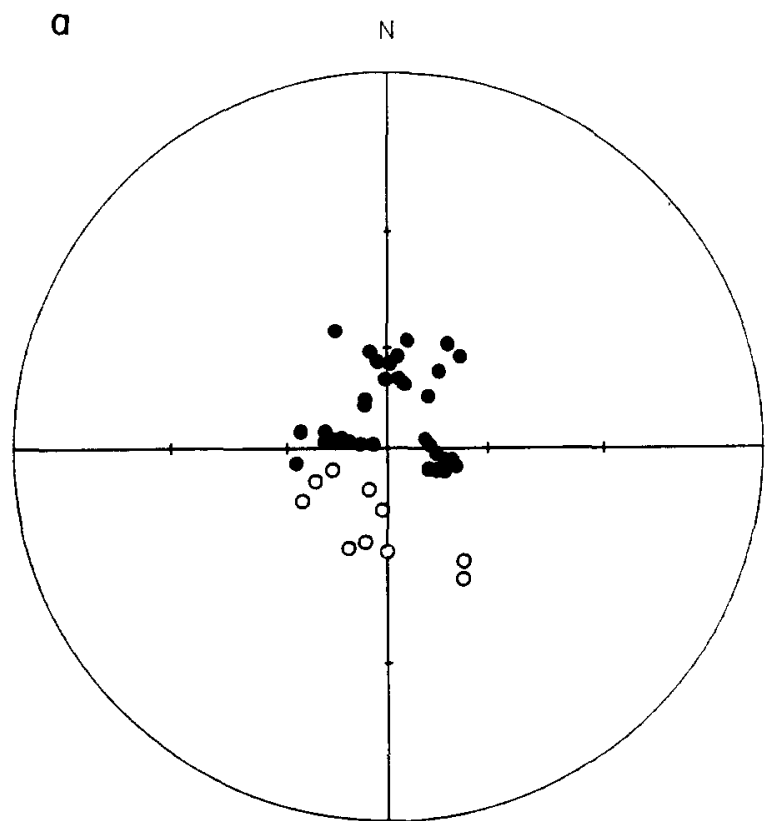

ples of one paragneiss site. These samples exhibited nearly univectorial behavior upon demagnetization (Fig. 2b). The direction removed was easterly and very steeply down $\left(D=103^{\circ}\right.$, $I=+74^{\circ}$ ). We believe this to be an ancient and probably Precambrian magnetization. It is similar to directions found in the other lithologies, as described below.

Of the six sites sampled in the anorthosite massif, one site was excluded from the analysis because there was no intra-site consistency of magnetic directions; the seven samples possessed random directions. Four more samples were eliminated from consideration because no stable magnetic direction could be isolated. The remaining 28 samples from five sites of the anorthosite complex gave coherent directions upon demagnetization. Most of these 28 samples possessed a low-temperature, low-coercivity component that proved to be a random direction most probably acquired during storage of the samples. However, all 28 samples revealed a very steep magnetic direction at tem-

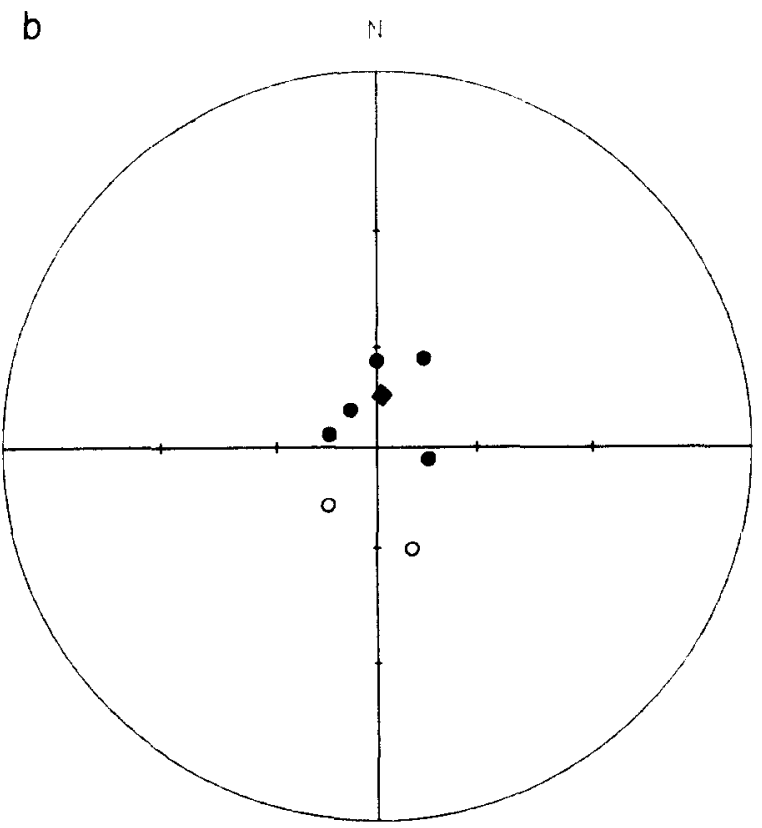

Fig. 3. Equal-angle stereographic projection of (a) sample directions and (b) site mean directions obtained from demagnetization analysis of the steep directions obtained from paragneiss, anorthosite and charnockite samples. $(O)$ are lower (upper) hemisphere projections; $\$$ is overall mean. 
peratures $>500^{\circ} \mathrm{C}$ and alternating fields $>20$ $\mathrm{mT}$. An example is shown in Fig. 2c. This direction was steeply down at four of the sites whereas one site possessed an antipodal, steeply up direction.

The six charnockite samples possessed a random component that was removed at low temperatures and alternating fields. At higher temperatures or fields, all six samples revealed a southwesterly and very steeply up magnetic direction, $D=220^{\circ}, I=-67^{\circ}$ (Fig. 2d).

Thus, we have isolated a very steep characteristic magnetic direction in the three different rock types studied. The sample directions and the site means of these characteristic magnetizations for the anorthosite, the paragneiss and the charnockite units are plotted in Fig. 3. The overall mean of these directions is $D=6^{\circ}$, $I=+74^{\circ}$.

Samples from all three lithologies were given an IRM up to a peak field of $1.4 \mathrm{~T}$ and all reached saturation below $0.3 \mathrm{~T}$. This behavior is indicative of magnetite and is consistent with the demagnetization results, which also suggest that magnetite is the dominant magnetic carrier.

\section{Discussion and conclusions}

We interpret the steep direction isolated from the anorthosite, paragneiss and charnockite to be a Precambrian direction that was acquired during the uplift and cooling of the Oaxacan orogenic belt. As mentioned earlier, the Oaxacan rocks are thought to have cooled to $\sim 600^{\circ} \mathrm{C}$ by $950 \mathrm{Ma}$. Given the discrete and high blocking temperatures of the steep, Precambrian directions of $550-600^{\circ} \mathrm{C}$ (Fig. 2), it is likely that the magnetization was acquired shortly after 950 Ma.

A significant problem with the paleomagnetism of igneous or metamorphic rocks is always the lack of knowledge about the structural tilting that occurred subsequent to the acquisition of magnetization. This study is no exception, but there are four lines of evidence that alle- viate this problem. First, Cretaceous rocks overlying the complex are essentially flat-lying, as observable in the field. Second, as already mentioned, McCabe et al. cited late Paleozoicearly Mesozoic remagnetizations from Paleozoic sedimentary rocks from Oaxaca that are very similar to our shallow, southerly direction which we have interpreted as a late Paleozoicearly Mesozoic remagnetization. The result of Gose and Sanchez-Barreda (1981) is likely to have the same origin. The similarity between all these directions, obtained over a large surface area, argues against significant post-Triassic structural tilting. Third, even if we were to allow for the possibility of a tilt to the WSW as the most logical choice (given the overall orientation of the massif) and similar to tilts observed elsewhere (in a small inlier of Paleozoic rocks outside our field area), the mean inclination would not change significantly. A tilt of $\sim 30^{\circ}$ would change the mean direction of $D /$ $I=6^{\circ} /+74^{\circ}$ to a westerly and steeply down direction (tilt corrected inclination of $\sim+65^{\circ}$ ); since our main conclusions of this paper are based on the inclination, not the declination, such a hypothetical correction would not significantly affect our paleolatitude comparison with other continental blocks. Fourth, we sampled across $>40 \mathrm{~km}$ of Proterozoic terrane yet the steep magnetic directions are consistent across the whole area, suggesting that there has been no differential tilting on a local scale. For such a large surface area, moreover, a large, post-orogenic and systematic tilting of $\sim 30^{\circ}$ would be extremely unlikely. For these reasons, we believe there is no need to suspect significant but undocumented structural tilting.

The paleomagnetic pole calculated from the steep magnetic direction at $47^{\circ} \mathrm{N}, 93^{\circ} \mathrm{W}$, falls at least $40^{\circ}$ away from the similar-age portion of the Grenville apparent polar wander path (APWP) for North America (Dunlop, 1981). Owing to the inherent uncertainty in declination at such steep inclination and, moreover, the possibility of local rotations, we have chosen to base our analysis primarily on the mean 
inclination measured in this study $\left(I=74^{\circ}\right)$ and the paleolatitude calculated from it $\left(60^{\circ}\right)$.

In this analysis, we first compare the paleolatitude of the Oaxacan complex with the paleolatitudes predicted for the Oaxacan Complex had it maintained its present-day spatial relationship to North America. Using pub-

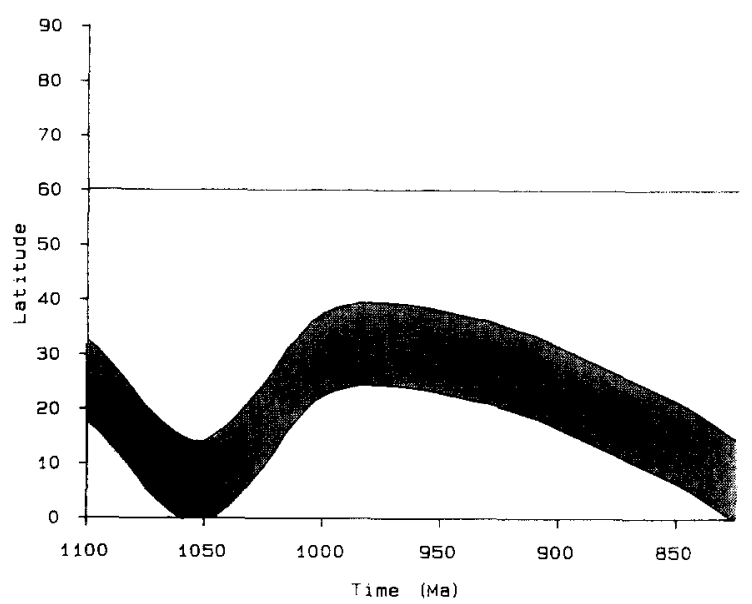

Fig. 4. Paleolatitude versus time plot. Gray swath represents predicted paleolatitude for Oaxaca, extrapolated from the Canadian Grenville poles, and the black line represents the observed paleolatitude for Oaxaca from this study $\left(60^{\circ}\right)$. lished results from Dunlop's (1981) APWP for the Grenville Province for the time 1100-825 $\mathrm{Ma}$, the paleolatitudes expected for Oaxaca during the entire time period have been calculated. It can be seen in Fig. 4 that the paleolatitude calculated from our steep magnetic direction, at $\sim 60^{\circ}$, does not match any predicted paleolatitudes for Oaxaca. A similar conclusion is reached when we examine Oaxaca restored to a possible Pangea configuration relative to North America using an $8^{\circ}$ counterclockwise rotation. From this, we conclude that neither the present-day nor a 'Pangea' position of Oaxaca relative to the North American Grenville Province can be reconciled with the steep magnetic direction found in our rocks. Oaxaca must have been relatively close to the pole during the time the rocks acquired their magnetization.

Using the results of this study, we have defined two constraints for the Precambrian paleogeographic position of the Oaxaca terrane:

(1) Oaxaca could not have occupied the same position relative to North America that it does today and,

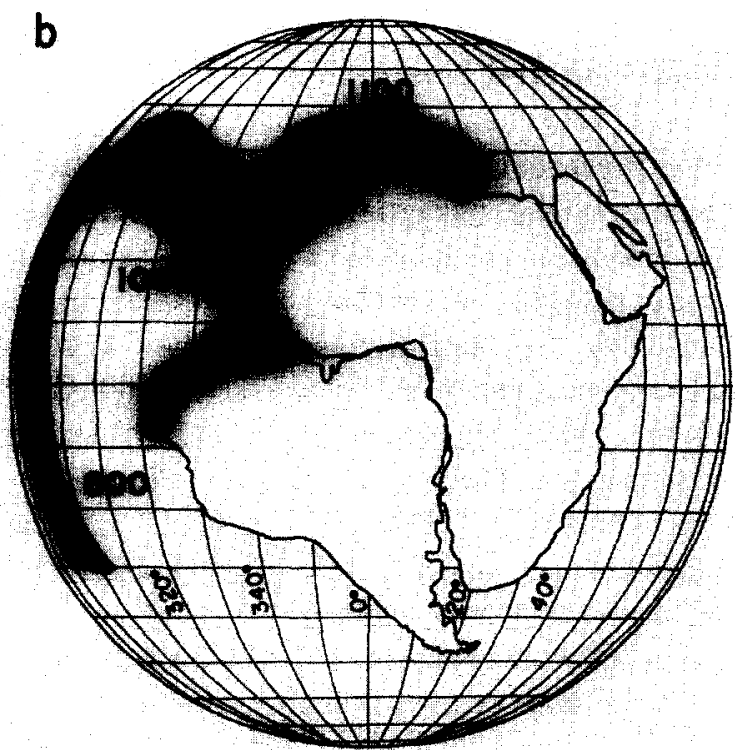

Fig. 5. Apparent polar wander path segments (medium-gray swaths) for the interval of 1100-800 Ma for (a) the North American craton (Dunlop, 1981) and (b) Africa/South America (McElhinny and McWilliams, 1977). The dark areas show the possible locations for the Oaxaca terrane, assuming that (1) it was located near one of the Grenville-aged provinces of the major cratons and (2) that it was located at a distance of $\sim 30^{\circ}$ from the pole, i.e., at a paleolatitude of $60^{\circ}$. 
(2) Oaxaca was located $30^{\circ}$ away from the magnetic pole when the magnetization was acquired.

In addition, it is likely that the Oaxaca terrane was located near one of the large Precambrian continental masses with Grenville-aged mobile belts, either Laurentia/Baltica or Africa/South America.

With these constraints in mind, we examined the appropriate portions of the North American (Dunlop, 1981) and African/South American (McElhinny and McWilliams, 1977; Vilas, 1981) APWPs (Fig. 5; medium gray shaded paths). We found that at $\sim 950 \mathrm{Ma}$, the North American APWP allows a range of paleopositions (dark shading in Fig. 5a) for the Oaxaca terrane adjacent to the Ontario/Quebec Grenville Province. It must be noted that the North American pole path is constrained much better than that for Africa/South America; thus, our conclusions must be regarded as tentative until the latter has been better defined. Examination of the African/South American APWP (Fig. $5 \mathrm{~b})$ reveals that the Oaxaca terrane could have had a paleoposition near West Africa or northwestern South America only for the time prior to $1000 \mathrm{Ma}$ or after $\sim 800 \mathrm{Ma}$. Given the age of the magnetization as $950 \mathrm{Ma}$ at the time of postmetamorphic cooling, we therefore prefer a paleoposition for Oaxaca adjacent to the Canadian Grenville Province.

How Oaxaca travelled from this Precambrian paleoposition to its geographical setting of today can only be resolved by future paleomagnetic work. The Gondwana affinity of Oaxacan trilobites may be taken as evidence for a complex history of the Oaxacan displaced terrane during the latest Precambrian and early Paleozoic.

\section{Acknowledgments}

We thank Roberto Molina-Garza for his valuable assistance in the field and Fernando Ortega-Gutierrez and Dante Moran-Zenteno for advice on the geology of the area. This study was supported by the Division of Earth Sciences, the National Science Foundation, grant EAR 83-13085.

\section{References}

Anderson, T.H. and Silver, L.T., 1971. Age of granulite metamorphism during the Oaxacan orogeny, Mexico. Geol. Soc. Am., Abstr. with Programs, 3: 492.

De Cserna, Z., 1971. Precambrian sedimentation, tectonics, and magmatism in Mexico. Geol. Rundschau, 60: 1488-1513.

Dewey, J.F. and Burke, K.C.A., 1973. Tibetan, Variscan, and Precambrian basement reactivation products of continental collision. J. Geol., 81: 683-692.

Dunlop, D.J., 1981. Paleomagnetic evidence for Proterozoic continental development. Philos. Trans. R. Soc. London, Ser. A, 301: 265-277.

Engel, A.E.J., 1963. Geologic evolution of North America. Science, 140: 143-152.

Fries Jr. C., and Rincón-Orta, C., 1965. Nuevas aportaciones geocronológicas y técnicas empleadas en el laboratorio de geochronologia. Bol. Inst. Geol., Universidad Nacional Autónoma de México, 73: 57-133.

Fries Jr., C., Schmitter-Villada, E., Damon, P.E. and Livingston, D.E., 1962. Rocas Precámbricas de edad Grenvilliana de la parte central de Oaxaca en el sur de México. Bol. Inst. Geol., Universidad Nacional Autónoma de México, 64: 45-53.

Fries Jr., C., Schlaepfer, C.J. and Rincón-Orta, C., 1966. Nuevos datos geocronológicos del Complejo Oaxaqueño. Bol. Soc. Geol. Mex., 29: 59-66.

Fries Jr., C., Rincón-Orta, C., Silver, L.T., McDowell, F.W., Solorio-Munguia, J., Schmitter-Villada, E. and De Cserna, Z., 1974. Nuevas aportaciones a la geocronologia de la faja tectonica Oaxaqueña. Bol. Assoc. Mex. Geol. Petr., 26: 157-182.

Gose, W.A. and Sanchez-Barreda, L., 1981. Paleomagnetic results from southern Mexico. Geof. Int., 20: 163-175.

Humphries, F.J. and Cliff, R.A., 1982. Sm-Nd dating and cooling history of Scourian granulites, Sutherland, NW Scotland. Nature, 295: 515-517.

Kesler, S.E., 1973. Basement rock structural trends in southern Mexico. Geol. Soc. Am. Bull., 84: 1059-1964.

Kesler, S.E. and Heath, S.A., 1970. Structural trends in southernmost North American Precambrian, Oaxaca, Mexico. Geol. Soc. Am. Bull., 81: 2471-2476.

Kirschvink, J.L., 1980. The least-squares line and plane and analysis of paleomagnetic data. Geophys. J. R. Astron. Soc., 45: 699-718.

McCabe, C., Van der Voo, R. and Urrutia-Fucugauchi, J., 1984. Paleomagnetism of the Tremadocian Tinu Limestone, State of Oaxaca, Mexico. EOS Trans. Am. Geophys. Union, 65: 868. 
McCabe, C., Van der Voo, R. and Urrutia-Fucugauchi, J., 1985. Paleomagnetism of Paleozoic sedimentary rocks and associated intrusives, State of Oaxaca, Mexico. EOS Trans. Am. Geophys. Union, 66: 865.

McElhinny, M.W. and McWilliams, M.O., 1977. Precambrian Geodynamics-a paleomagnetic view. Tectonophysics, 40: 137-159.

Mora, C.I. and Valley, J.W., 1985. Ternary feldspar thermometry in granulites from the Oaxacan complex, southern Mexico. Contrib. Mineral. Petrol., 89: 215-225.

Ortega-Gutierrez, F., 1981. Metamorphic belts of southern Mexico and their tectonic significance. Geof. Int., 20: 177-202.

Ortega-Gutierrez, F., 1986. Precambrian basement terranes of the southern Gulf of Mexico-northern Caribbean region. Geol. Soc. Am. Abstr. with Progs. 8: 710.

Ortega-Gutierrez, F., Anderson, T.H. and Silver, L.T., 1977. Lithologies and geochronology of the Precambrian craton of southern Mexico. Geol. Soc. Am. Abstr. with Prog., 9: 1121-1122.

Patchett, P.J. and Ruiz, J., 1987. Nd isotopic ages of crust formation and metamorphism in the Precambrian of eastern and southern Mexico. Contrib. Mineral. Petrol., 96: 523-528.

Ruiz-Castellanos, M., 1979. Rb-Sr geochronology of the Oaxaca and Acatlán metamorphic areas of southern Mexico. Ph.D. Dissertation, University of Texas, Dallas, 178 pp. (unpublished).

Vilas, J.F.A., 1981. Palaeomagnetism of South American rocks and the dynamic processes related with the fragmentation of western Gondwana. In: M.W. McElhinny and D.A. Valencio (Editors), Paleoreconstruction of the Continents, Geodynamics Series, Vol. 2. American Geophysical Union, Washington, DC, pp. 106-114.

Whittington, H.B. and Hughes, C.P., 1974. Geography and faunal provinces in the Tremadoc epoch. Soc. Econ. Paleont. Mineral. Spec. Publ., 21: 203-218.

Zijderveld, J.D.A., 1967. A.C. demagnetization of rocks: analysis of results. In: D.W. Collinson, K.M. Creer and S.K. Runcorn (Editors), Methods in Paleomagnetism. Elsevier, Amsterdam, pp. 245-286. 